\title{
Photosynthesis-irradiance parameters of marine phytoplankton: synthesis of a global data set
}

\author{
Heather A. Bouman ${ }^{1}$, Trevor Platt ${ }^{2}$, Martina Doblin ${ }^{3}$, Francisco G. Figueiras ${ }^{4}$, Kristinn Gudmundsson ${ }^{5}$, \\ Hafsteinn G. Gudfinnsson ${ }^{5}$, Bangqin Huang ${ }^{6}$, Anna Hickman ${ }^{7}$, Michael Hiscock ${ }^{8}$, Thomas Jackson ${ }^{2}$, \\ Vivian A. Lutz ${ }^{9}$, Frédéric Mélin ${ }^{10}$, Francisco Rey ${ }^{11}$, Pierre Pepin ${ }^{12}$, Valeria Segura ${ }^{9}$, Gavin H. Tilstone ${ }^{2}$, \\ Virginie van Dongen-Vogels ${ }^{3}$, and Shubha Sathyendranath ${ }^{2,13}$ \\ ${ }^{1}$ Department of Earth Sciences, University of Oxford, Oxford, OX1 3AN, UK \\ ${ }^{2}$ Plymouth Marine Laboratory, Prospect Place, The Hoe, PL1 3DH, UK \\ ${ }^{3}$ Plant Functional Biology and Climate Change Cluster, Faculty of Science, University of Technology Sydney, \\ P.O. Box 123 Broadway, Sydney, NSW 2007, Australia \\ ${ }^{4}$ Instituto de Investigaciones Marinas (CSIC), Eduardo Cabello 6, 36208 Vigo, Spain \\ ${ }^{5}$ Marine Research Institute, P.O. Box 1390, 121 Reykjavík, Iceland \\ ${ }^{6}$ State Key Laboratory of Marine Environmental Science/Key Laboratory of Coastal and Wetland Ecosystems, \\ Ministry of Education, Xiamen University, Xiamen, Fujian 361005, China \\ ${ }^{7}$ Ocean and Earth Science, University of Southampton, National Oceanography Centre Southampton, \\ European Way, Southampton, SO14 3ZH, UK \\ ${ }^{8}$ United States Environmental Protection Agency, Ariel Rios Building, 1200 Pennsylvania Avenue, \\ Washington D.C., 20460, USA \\ ${ }^{9}$ Instituto Nacional de Investigacion y Desarrollo Pesquero, Mar del Plata, Argentina \\ ${ }^{10}$ European Commission, Joint Research Centre, Ispra 21027, Italy \\ ${ }^{11}$ Institute of Marine Research, c/o Department of Biological Sciences, University of Oslo, \\ P.O. Box 1066, 0316, Oslo, Norway \\ ${ }^{12}$ Fisheries and Oceans Canada, Northwest Atlantic Fisheries Centre, P.O. Box 5667, St John’s, \\ Newfoundland, A1C 5X1, Canada \\ ${ }^{13}$ National Centre for Earth Observation, Plymouth Marine Laboratory, Prospect Place, \\ Plymouth PL1 3DH, UK
}

Correspondence: Heather A. Bouman (heather.bouman@earth.ox.ac.uk)

Received: 15 May 2017 - Discussion started: 7 June 2017

Revised: 24 November 2017 - Accepted: 2 December 2017 - Published: 6 February 2018

\begin{abstract}
The photosynthetic performance of marine phytoplankton varies in response to a variety of factors, environmental and taxonomic. One of the aims of the MArine primary Production: model Parameters from Space (MAPPS) project of the European Space Agency is to assemble a global database of photosynthesisirradiance $(P-E)$ parameters from a range of oceanographic regimes as an aid to examining the basin-scale variability in the photophysiological response of marine phytoplankton and to use this information to improve the assignment of $P-E$ parameters in the estimation of global marine primary production using satellite data. The MAPPS $P-E$ database, which consists of over $5000 P-E$ experiments, provides information on the spatiotemporal variability in the two $P-E$ parameters (the assimilation number, $P_{m}^{B}$, and the initial slope, $\alpha^{B}$, where the superscripts $B$ indicate normalisation to concentration of chlorophyll) that are fundamental inputs for models (satellite-based and otherwise) of marine primary production that use chlorophyll as the state variable. Qualitycontrol measures consisted of removing samples with abnormally high parameter values and flags were added to denote whether the spectral quality of the incubator lamp was used to calculate a broad-band value of $\alpha^{B}$. The MAPPS database provides a photophysiological data set that is unprecedented in number of observations and in spatial coverage. The database will be useful to a variety of research communities, including marine ecologists,
\end{abstract}


biogeochemical modellers, remote-sensing scientists and algal physiologists. The compiled data are available at https://doi.org/10.1594/PANGAEA.874087 (Bouman et al., 2017).

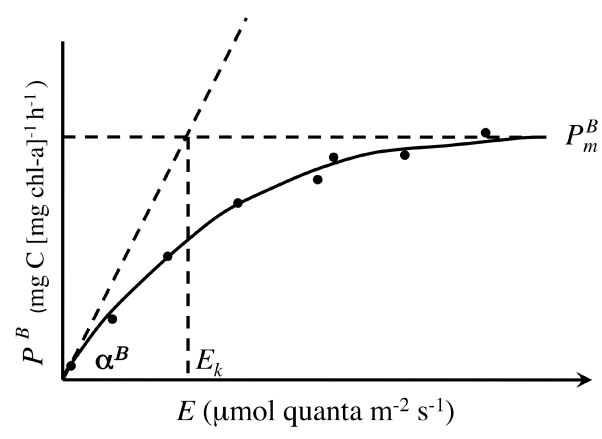

Figure 1. Photosynthesis-irradiance $(P-E)$ curve showing the two biomass-normalised photophysiological parameters, the maximum photosynthetic rate $P_{m}^{B}$ and the initial slope $\alpha^{B}$.

\section{Introduction}

Although global estimates of marine primary production tend to converge on a number around $40-50 \mathrm{GT} \mathrm{yr}^{-1}$, the accuracy and precision on regional scales of the estimation protocols remain relatively poor, partly as a result of an incomplete understanding of how the photosynthetic performance of marine phytoplankton varies in the global ocean (Carr et al., 2006; Lee et al., 2015). Photosynthesis-irradiance ( $P$ $E)$ parameters derived from carbon uptake experiments conducted over a controlled range of available-light levels provide a means of comparing the photosynthetic characteristics of marine phytoplankton across different natural populations and cultured isolates (Platt and Jassby, 1976; Prézelin et al., 1989; MacIntyre et al., 2002). The $P$ - $E$ experiment exposes algal cells to a range of light intensities from nearzero to those levels typically available at the sea surface (Lewis and Smith, 1983; Babin et al., 1994). The photosynthetic rates are then normalised to the concentration of chlorophyll $a$ (a useful and practical index of phytoplankton biomass relevant for photosynthesis) found within the sample. This normalisation serves two purposes: first, dividing by pigment biomass reduces the variability of photosynthesis rates due to differences in biomass alone, facilitating the comparison of photosynthetic performance across trophic gradients, and second, chlorophyll-normalised photophysiological parameters may be applied in the estimation of primary production over large scales by using satellite-derived maps of chlorophyll concentration (Longhurst et al., 1995; Antoine and Morel, 1996). A schematic diagram showing the biomass-normalised data generated from these experiments plotted against the light intensity at which each bottle was incubated is shown in Fig. 1 to illustrate how the ensemble of data, when fitted to a suitable non-linear equation, forms a $P$ $E$ curve. The curve may be represented by a variety of mathematical forms (Jassby and Platt, 1976; Platt et al., 1980). In cases where photoinhibition is negligible, all equations suitable for describing the $P-E$ curve can be represented using just two parameters: the initial slope, $\alpha^{B}$, which represents the photosynthetic efficiency under light levels close to zero, and the asymptote of the curve, $P_{m}^{B}$, which is the photosynthetic rate at light saturation (Jassby and Platt, 1976; Platt et al., 1980; Sakshaug et al., 1997).

\section{Data}

Chlorophyll $a$ concentrations and photosynthesis-irradiance $(P-E)$ parameters collected from four oceanic domains and 35 biogeochemical provinces (Longhurst, 2007, Table 1) were compiled from individual investigators and online data repositories (Table 2). $P-E$ data were obtained by ${ }^{14} \mathrm{C}$ and ${ }^{13} \mathrm{C}$ (Argentine Sea) uptake experiments, with incubation times varying from 1.5 to $4 \mathrm{~h}$. Chlorophyll concentrations used to normalise the carbon fixation rates were measured using either high-performance liquid chromatography (HPLC) or the standard fluorometric method (Mantoura et al., 1997). An intercomparison between HPLC and fluorometrically determined chlorophyll $a$ concentrations revealed that pheopigment-correcting acidification methods such as Holm-Hansen et al. (1965) show a good overall correlation $\left(r^{2}=0.85\right)$. However, the study noted that the presence of the accessory pigment chlorophyll $b$ could lead to an underestimation of chlorophyll $a$ concentration by $2-19 \%$ (Martoura et al., 1997). This potential source of bias in fluorometrically determined chlorophyll $a$ concentration would result in an overestimation of the chlorophyll $a$ normalised photosynthetic parameters of up to $19 \%$ where relative chlorophyll $b$ concentrations are high (e.g. the deep chlorophyll maxima of the subtropical gyres). Further details on the experimental methodology for individual field campaigns are provided in the original publications (see Table 2). The environmental variables and photosynthetic parameters included the MAPPS database and their corresponding units are listed in Table 3.

Table 2 includes information on which functional form was fitted to the $P-E$ data for each of the data sets used in this study. In cases where photoinhibition was absent (photosynthetic rates stayed independent of irradiance in the lightsaturated range), or where the fit was applied to data unaffected by photoinhibition, a two-parameter curve fit was 
Table 1. Numbers corresponding to biogeochemical province and domain as described by Longhurst (2007) included in the MAPPS database.

\begin{tabular}{|c|c|c|}
\hline $\begin{array}{l}\text { Province } \\
\text { number }\end{array}$ & Longhurst domain & Longhurst province \\
\hline 1 & Polar & Boreal Polar Province \\
\hline 2 & Polar & Atlantic Arctic Province \\
\hline 3 & Polar & Atlantic Subarctic Province \\
\hline 4 & Westerlies & North Atlantic Drift Province \\
\hline 5 & Westerlies & Gulf Stream Province \\
\hline 6 & Westerlies & North Atlantic Subtropical Gyre Province (West) \\
\hline 7 & Trades & North Atlantic Tropical Gyre Province \\
\hline 8 & Trades & Western Tropical Atlantic Province \\
\hline 9 & Trades & Eastern Tropical Atlantic Province \\
\hline 10 & Trades & South Atlantic Gyre Province \\
\hline 11 & Coastal & North East Atlantic Shelves Province \\
\hline 12 & Coastal & Canary Coastal Province \\
\hline 15 & Coastal & North West Atlantic Shelves Province \\
\hline 17 & Trades & Caribbean Province \\
\hline 18 & Westerlies & North Atlantic Subtropical Gyre Province (East) \\
\hline 20 & Coastal & Brazil Current Coastal Province \\
\hline 21 & Coastal & South West Atlantic Shelves Province \\
\hline 22 & Coastal & Benguela Current Coastal Province \\
\hline 30 & Trades & Indian Monsoon Gyres Province \\
\hline 33 & Coastal & Red Sea, Persian Gulf Province \\
\hline 34 & Coastal & North West Arabian Upwelling Province \\
\hline 37 & Coastal & Australia-Indonesia Coastal Province \\
\hline 50 & Polar & North Pacific Epicontinental Province \\
\hline 51 & Westerlies & Pacific Subarctic Gyres Province (East) \\
\hline 53 & Westerlies & Kuroshio Current Province \\
\hline 58 & Westerlies & Tasman Sea Province \\
\hline 60 & Trades & N. Pacific Tropical Gyre Province \\
\hline 63 & Trades & W. Pacific Warm Pool Province \\
\hline 64 & Trades & Archipelagic Deep Basins Province \\
\hline 68 & Coastal & Chile-Peru Current Coastal Province \\
\hline 69 & Coastal & China Sea Coastal Province \\
\hline 80 & Westerlies & S. Subtropical Convergence Province \\
\hline 81 & Westerlies & Subantarctic Province \\
\hline 82 & Polar & Antarctic Province \\
\hline 83 & Polar & Austral Polar Province \\
\hline
\end{tabular}

used, of the form

$P^{B}(E)=P_{m}^{B} \tanh \left(\frac{\alpha^{B} E}{P_{m}^{B}}\right)$,

where $P^{B}(E)$ is the chlorophyll-normalised photosynthetic rate $\left(\mathrm{mgC}(\mathrm{mgChl} a)^{-1} \mathrm{~h}^{-1}\right)$ and $E$ is the available light, which in this study is expressed in $\mu$ mol quanta $\mathrm{m}^{-2} \mathrm{~s}^{-1}$. The light saturation parameter, $E_{k}$, is defined by the following relationship,

$E_{k}=\frac{P_{m}^{B}}{\alpha^{B}}$

and is illustrated in Fig. 1 by the drawing a line from the intersection of the initial slope with the plateau of the curve onto the abscissa and has dimensions of irradiance.
In most cases, however, data were fit to the threeparameter function of Platt et al. (1980), which also describes the decrease in photosynthetic rate with irradiances much higher than saturating light levels, as follows:

$$
P^{B}(E)=P_{s}^{B}\left(1-\exp \left(-\frac{\alpha^{B} E}{P_{s}^{B}}\right)\right) \exp \left(-\frac{\beta^{B} E}{P_{s}^{B}}\right),
$$

where $\beta^{B}$ is the photoinhibition parameter describing the decrease in photosynthetic rate at high irradiance and $P_{s}^{B}$ is the hypothetical maximum photosynthetic rate in the absence of photoinhibition. Hence when $\beta^{B}=0, P_{s}^{B}=P_{m}^{B}$. When photoinhibition was present, values of $P_{m}^{B}$ were derived using the following equation:

$$
P_{m}^{B}=P_{s}^{B}\left(\frac{\alpha^{B}}{\alpha^{B}+\beta^{B}}\right)\left(\frac{\beta^{B}}{\alpha^{B}+\beta^{B}}\right)^{\frac{\beta}{\alpha}} .
$$


Table 2. Summary of contributions to the MAPPS database.

\begin{tabular}{|c|c|c|c|c|c|c|}
\hline Dataset provider & Regions & Dates & $N$ & $\begin{array}{l}\text { Non-linear equation(s) fitted } \\
\text { to experimental data }\end{array}$ & Database & Relevant publication(s) \\
\hline $\begin{array}{l}\text { Trevor Platt, } \\
\text { Plymouth Marine Laboratory } \\
\text { (tplatt@dal.ca) }\end{array}$ & $\begin{array}{l}\text { Arctic, Arabian Sea, Azores, } \\
\text { Caribbean Sea, Celtic Sea, } \\
\text { Georges Bank, Grand Banks, } \\
\text { Humboldt Current System, } \\
\text { Hudson Bay, Labrador Sea, Mid- } \\
\text { Atlantic Ridge, New England } \\
\text { Seamounts, Sargasso Sea, } \\
\text { Scotian Shelf, Vancouver Island }\end{array}$ & $\begin{array}{l}1977- \\
2003\end{array}$ & 2146 & $\begin{array}{l}\text { Photoinhibition function } \\
\text { (Platt et al., 1980) }\end{array}$ & $\begin{array}{l}\text { BIOCHEM } \\
\text { (www.meds-sdmm.dfo-mpo. } \\
\text { gc.ca) }\end{array}$ & $\begin{array}{l}\text { Bouman et al. (2005); Har- } \\
\text { rison and Platt (1986); Kye- } \\
\text { walyanga et al. (1998); Platt } \\
\text { et al. (1980); Platt et al. (1982); } \\
\text { Platt et al. (1993); Sathyen- } \\
\text { dranath et al. (1999) }\end{array}$ \\
\hline $\begin{array}{l}\text { Francisco Rey, } \\
\text { Institute of Marine Research } \\
\text { (pancho@IMR.no) }\end{array}$ & Barents Sea & $\begin{array}{l}1980- \\
1989\end{array}$ & 223 & $\begin{array}{l}\text { Photoinhibition function } \\
\text { (Platt et al., 1980) }\end{array}$ & & Rey (1991) \\
\hline $\begin{array}{l}\text { Pierre Pepin, } \\
\text { Fisheries and Oceans Canada, } \\
\text { Northwest Atlantic Fisheries Cen- } \\
\text { tre } \\
\text { (pierre.pepin@dfo-mpo.gc.ca) }\end{array}$ & Grand Banks & $\begin{array}{l}2004- \\
2012\end{array}$ & 524 & $\begin{array}{ll}\text { Photoinhibition } & \text { function } \\
\text { (Platt et al., 1980) } & \end{array}$ & & Unpublished \\
\hline $\begin{array}{l}\text { Heather Bouman, } \\
\text { University of Oxford } \\
\text { (heather.bouman@earth.ox.ac.uk) }\end{array}$ & $\begin{array}{l}\text { Subtropical Atlantic, } \\
\text { Greenland Sea, Norwegian Sea }\end{array}$ & $\begin{array}{l}1996 \\
2010 \\
2013\end{array}$ & 195 & $\begin{array}{l}\text { Photoinhibition function } \\
\text { (Platt et al., 1980) }\end{array}$ & & $\begin{array}{l}\text { Bouman et al. (2000a); Jackson } \\
\text { (2013); Bouman (unpublished) }\end{array}$ \\
\hline $\begin{array}{l}\text { Michael Hiscock, } \\
\text { National Center for Environ- } \\
\text { mental Research US Envi- } \\
\text { ronmental Protection Agency } \\
\text { (hiscock.michael@epa.gov) }\end{array}$ & Southern Ocean - Pacific sector & $\begin{array}{l}1997- \\
1998\end{array}$ & 172 & $\begin{array}{ll}\text { Photoinhibition } & \text { function } \\
\text { (Platt et al., 1980) } & \end{array}$ & & $\begin{array}{l}\text { Hiscock (2004); Hiscock } \\
\text { et al. (2003) }\end{array}$ \\
\hline $\begin{array}{l}\text { Vivian Lutz, Instituto Nacional de } \\
\text { Investigación y Desarrollo Pes- } \\
\text { quero } \\
\text { (vlutz@inidep.edu.ar) }\end{array}$ & Argentine Sea & $\begin{array}{l}2005- \\
2006\end{array}$ & 69 & $\begin{array}{ll}\text { Photoinhibition } & \text { function } \\
\text { (Platt et al., 1980) } & \end{array}$ & & $\begin{array}{l}\text { Dogliotti et al. } \\
\text { Lutz et al. (2014); } \\
\text { et al. (2013) }\end{array}$ \\
\hline $\begin{array}{l}\text { Gavin Tilstone, } \\
\text { Plymouth Marine Laboratory } \\
\text { (ghti@pml.ac.uk) }\end{array}$ & $\begin{array}{l}\text { Benguela upwelling system, east- } \\
\text { ern tropical Atlantic, North At- } \\
\text { lantic Subtropical Gyre, Canary } \\
\text { coastal system, North Atlantic } \\
\text { Drift Province }\end{array}$ & 1998 & 129 & $\begin{array}{l}\text { Photoinhibition function } \\
\text { (Platt et al., 1980) }\end{array}$ & BODC (www.bodc.ac.uk) & Tilstone et al. (2003) \\
\hline $\begin{array}{l}\text { Bangqin Huang, } \\
\text { State Key Laboratory of Marine } \\
\text { Environmental Science/Key Lab- } \\
\text { oratory of Coastal and Wetland } \\
\text { Ecosystems Ministry of Education, } \\
\text { Xiamen University } \\
\text { (bqhuang@xmu.edu.cn) }\end{array}$ & South China Sea & $\begin{array}{l}2010- \\
2012\end{array}$ & 130 & $\begin{array}{l}\text { Photoinhibition function } \\
\text { (Platt et al., 1980) }\end{array}$ & & Xie et al. (2015) \\
\hline $\begin{array}{l}\text { Anna Hickman, National } \\
\text { Oceanography Centre Southamp- } \\
\text { ton } \\
\text { (a.hickman@noc.soton.ac.uk) }\end{array}$ & $\begin{array}{l}\text { North Atlantic Subtropical Gyre, } \\
\text { North Atlantic Drift Province, } \\
\text { Canary coastal system, South At- } \\
\text { lantic Subtropical Gyre, western } \\
\text { tropical Atlantic }\end{array}$ & 2004 & 31 & $\begin{array}{l}\text { Hyperbolic tangent function } \\
\text { (Jassby and Platt, 1976). }\end{array}$ & BODC (www.bodc.ac.uk) & $\begin{array}{l}\text { Hickman (2007); Lawrenz } \\
\text { et al. (2013) }\end{array}$ \\
\hline $\begin{array}{l}\text { Kristinn Gudmundsson, } \\
\text { Marine Research Institute, Iceland } \\
\text { (kristinn@hafro.is) }\end{array}$ & Iceland and Faroes & $\begin{array}{l}1981- \\
2007\end{array}$ & 559 & $\begin{array}{l}\text { Photoinhibition function } \\
\text { (Platt et al., 1980) and hy- } \\
\text { perbolic tangent function } \\
\text { (Jassby and Platt, 1976). }\end{array}$ & & $\begin{array}{l}\text { Gudmundsson (1998); Pálsson } \\
\text { et al. (2012); Zhai et al. (2012) }\end{array}$ \\
\hline $\begin{array}{l}\text { Francisco G. Figueiras, Instituto de } \\
\text { Investigaciones Marinas (CSIC) } \\
\text { Eduardo Cabello 6, } 36208 \text { Vigo, } \\
\text { Spain } \\
\text { (paco@iim.csic.es) }\end{array}$ & Antarctic Peninsula & 1995 & 51 & $\begin{array}{l}\text { Exponential without photoin- } \\
\text { hibition } \\
\text { Webb et al. (1974) }\end{array}$ & $\begin{array}{l}\text { JGOFS International Collection } \\
\text { Volume 1: Discrete Datasets } \\
(1989-2000) \text { DVD }\end{array}$ & Lorenzo et al. (2002) \\
\hline $\begin{array}{l}\text { Martina Doblin, } \\
\text { University of Technology, Sydney } \\
\text { (martina.doblin@uts.edu.au) }\end{array}$ & $\begin{array}{l}\text { Southern Ocean, Antarctic } \\
\text { Peninsula, Tasman Sea }\end{array}$ & $\begin{array}{l}1990- \\
2013\end{array}$ & 1482 & $\begin{array}{l}\text { Photoinhibition function } \\
\text { (Platt et al., 1980) }\end{array}$ & $\begin{array}{l}\text { AADC (https://data.aad.gov.au/ } \\
\text { metadata) } \\
\text { MARLIN } \\
\text { (http://www.marine.csiro. } \\
\text { au/marq/edd_search. } \\
\text { search_choice?tFre= } \\
\text { primary+production\&ch1= } \\
\text { freetext\&cSub=\%3E\%3E) } \\
\text { CSIRO Marine National Facil- } \\
\text { ity (http://www.marine.csiro. } \\
\text { au/nationalfacility/voyages/ } \\
\text { datasets.htm) } \\
\text { PANGAEA } \\
\text { (http://doi.pangaea.de/10. } \\
\text { 1594/PANGAEA.103773, } \\
\text { http://doi.pangaea.de/10.1594/ } \\
\text { PANGAEA.843554, }\end{array}$ & $\begin{array}{l}\text { Mackey et al. (1995); Grif- } \\
\text { fiths et al. (1999); Hanson } \\
\text { et al. (2005a); Hanson } \\
\text { et al. (2005b); Westwood } \\
\text { et al. (2011) }\end{array}$ \\
\hline
\end{tabular}


Table 3. List of environmental variables and $P-E$ parameters in the MAPPS database and their corresponding units.

\begin{tabular}{|c|c|c|}
\hline Header & Description & Units \\
\hline LAT & Latitude of sampling station & Decimal degrees \\
\hline LON & Longitude of sampling station & Decimal degrees \\
\hline DEPTH & Depth at which sample was collected & $\mathrm{m}$ \\
\hline YEAR & Year of sample collection & \\
\hline MONTH & Month of sample collection & \\
\hline DAY & Day of sample collection & \\
\hline TCHL & $\begin{array}{l}\text { Chlorophyll concentration measured using either high- } \\
\text { performance liquid chromatography or the fluorometric } \\
\text { method. }\end{array}$ & $\operatorname{mgChl} a \mathrm{~m}^{-3}$ \\
\hline ALPHA & $\begin{array}{l}\alpha^{B} \text {, the initial slope of the photosynthesis-irradiance curve nor- } \\
\text { malised to phytoplankton chlorophyll concentration. }\end{array}$ & $\operatorname{mgC}(\operatorname{mgChl} a)^{-1} \mathrm{~h}^{-1}\left(\mu \text { mol quanta } \mathrm{m}^{-2} \mathrm{~s}^{-1}\right)^{-1}$ \\
\hline PMB & $\begin{array}{l}P_{m}^{B} \text {, the rate of photosynthesis at saturating irradiance, nor- } \\
\text { malised to phytoplankton chlorophyll concentration. }\end{array}$ & $\operatorname{mgC}(\mathrm{mgChl} a)^{-1} \mathrm{~h}^{-1}$ \\
\hline EK & $\begin{array}{l}E_{k} \text {, irradiance at which the onset of saturation occurs, calcu- } \\
\text { lated as the ratio of } P_{m}^{B} \text { to } \alpha^{B} \text {. }\end{array}$ & $\mu$ mol quanta $\mathrm{m}^{-2} \mathrm{~s}^{-1}$ \\
\hline PROVNUM & $\begin{array}{l}\text { The corresponding biogeochemical province defined by } \\
\text { Longhurst (please refer to Table 2). }\end{array}$ & \\
\hline
\end{tabular}

\section{Quality control for the MAPPS P-E database}

\subsection{Experimental conditions}

The $P-E$ experiments were performed in incubators that maintained samples under in situ temperature conditions using either temperature-controlled water baths or the ship's underway water supply. Samples where incubation temperatures differed from in situ temperatures by more than $2{ }^{\circ} \mathrm{C}$ were removed from the database. It is well known that the light spectrum has a significant effect on the magnitude of light-limited photosynthesis $\left(\alpha^{B}\right)$ and the derived light saturation parameter $\left(E_{k}\right)$ (Kyewalyanga et al., 1997; Schofield et al., 1991). We have included in the database quality flags indicating whether a correction factor for the spectrum of the lamp was applied to obtain a readily intercomparable broadband (white light) value (e.g. Kyewalyanga et al., 1997; Xie et al., 2015). This broad-band $\alpha^{B}$ combined with information on the shape of the phytoplankton absorption spectrum has been shown to provide an accurate estimate of the photosynthetic action spectrum $\alpha^{B}(\lambda)$. The correction factor $X$ can be used to convert the measured $\alpha^{B}$ from the incubation experiment using a given artificial light source to an estimate of $\alpha^{B}$ if the sample were subject to a spectrally neutral light environment: it is the ratio of the unweighted mean absorption coefficient of phytoplankton $\left(\bar{a}_{\mathrm{p}}\right)$ to the mean absorption coefficient weighted by the shape of the emission spectrum of the lamp source $\left(\bar{a}_{\mathrm{L}}\right)$,

$X=\frac{\bar{a}_{\mathrm{p}}}{\bar{a}_{T}}$,

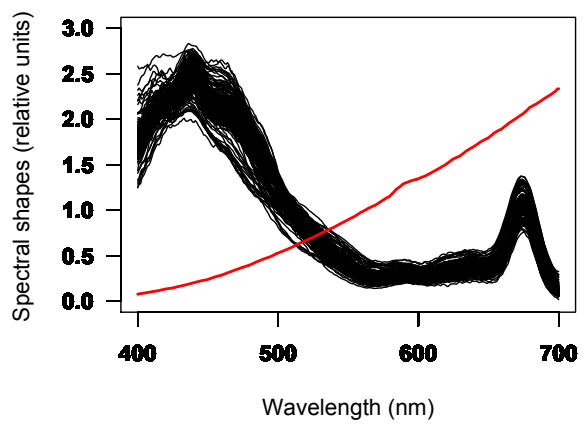

Figure 2. Spectral shapes of the tungsten-halogen lamp used in the incubations conducted by the Bedford Institute from 1984 to 2003 (red line) and in vivo absorption spectra of marine phytoplankton collected in the North Atlantic and subpolar waters (Labrador Sea). Phytoplankton and lamp spectra were normalised to their mean value to define the shape.

where $\bar{a}_{\mathrm{p}}$ is determined by

$\bar{a}_{\mathrm{p}}=\frac{\int_{400}^{700} a_{\mathrm{p}}(\lambda) \mathrm{d} \lambda}{\int_{400}^{700} \mathrm{~d} \lambda}$,

and $\bar{a}_{T}$ is computed as

$\bar{a}_{T}=\frac{\int_{400}^{700} a_{\mathrm{p}}(\lambda) E_{T}(\lambda) \mathrm{d} \lambda}{\int_{400}^{700} E_{T}(\lambda) \mathrm{d} \lambda}$.

The incubators in this study used a range of light sources, including tungsten halogen, halogen, metal halide, and fluorescent lamps. Tungsten halogen lamps are the most commonly used light source in $P-E$ experiments because they 
Table 4. Information on the light sources and filters used for photosynthesis-irradiance experiments for each of the data set providers. Also noted is whether the spectral correction of Kyewalyanga et al. (1997) shown in equation was applied to values of $\alpha^{B}$.

\begin{tabular}{|c|c|c|}
\hline Dataset provider & Lamp source details & $\begin{array}{l}\text { Spectral } \\
\text { correction }\end{array}$ \\
\hline \multirow[t]{4}{*}{ Platt } & GTE Sylvania PAR 150 & $\mathrm{~N}$ \\
\hline & $\begin{array}{l}\text { Combination of GTE Sylvania PAR } 150 \text { (irradiances }<200 \mathrm{~W} \text { ) and New Haline OHS tungsten } \\
\text { halogen (irradiances 200-1000 W) }\end{array}$ & $\mathrm{N}$ \\
\hline & $\begin{array}{l}2000 \mathrm{~W} \text { tungsten-halogen lamp (New Haline OHS 2000) with a maximum intensity of } \\
1000 \mathrm{~W} \mathrm{~m}^{-2} \text { (PAR) }\end{array}$ & $\mathrm{N}$ \\
\hline & $\begin{array}{l}\text { Gilway Technical Lamp L } 7391 \text { tungsten halogen. Spectral correction applied to samples col- } \\
\text { lected from } 1994 \text { onwards. }\end{array}$ & $\mathrm{Y}$ \\
\hline Rey & $\begin{array}{l}\text { Low-light incubator (LL, } 0 \text { to } 390 \mathrm{mmol} \mathrm{m}^{-2} \mathrm{~s}^{-1} \text { ) was equipped with daylight-type flu- } \\
\text { orescent tubes (OSRAM } 191 \text { Daylight } 5000 \text { de Luxe). High-light incubator (HL, } 0 \text { to } \\
1700 \mu \mathrm{mol} \mathrm{m}{ }^{-2} \mathrm{~s}^{-1} \text { ) was equipped with a halogen-metal lamp (OSRAM Power Star, } 400 \mathrm{~W} \text { ). }\end{array}$ & $\mathrm{N}$ \\
\hline Pepin & $\begin{array}{l}\text { ENH-type tungsten-halogen quartz projection lamps directed through a heat filter (solution of } \\
\text { copper sulfate } 20 \mathrm{gL}^{-1} \text { ) to remove the infrared emission (no additional corrections made). }\end{array}$ & $\mathrm{N}$ \\
\hline \multirow[t]{2}{*}{ Bouman } & Gilway Technical Lamp L 7391 tungsten halogen, Spectral correction applied. & Y \\
\hline & $\begin{array}{l}\text { Lee } 1 / 4 \mathrm{CT} \text { blue filter was placed in front of incubator window to diminish the spectral de- } \\
\text { pendency of the light source }(2 \times 50 \mathrm{~W} \text { Sylvania } 2315 \text { tungsten halogen }) \text {. Spectral correction } \\
\text { applied. }\end{array}$ & $\mathrm{Y}$ \\
\hline Hiscock & $\begin{array}{l}250 \mathrm{~W} \text { tungsten-halogen slide projector lamp (Gray Co. \#ENH), spectrally modified using a heat } \\
\text { mirror, a broad-band cool mirror (Optical Coating Laboratory, Inc.), and blue stage-lighting } \\
\text { screens (Cinemills Corp. \#M144). }\end{array}$ & Y \\
\hline Lutz & $70 \mathrm{~W}$ Westinghouse halogen lamp. Spectral correction applied. & Y \\
\hline Tilstone & $\begin{array}{l}\text { AMT } 6 \text { and 20: tungsten-halogen lamps spectrally corrected. AMT 23: both tungsten-halogen } \\
\text { and LED lamps used and spectrally corrected. }\end{array}$ & $\mathrm{Y}$ \\
\hline Huang & $150 \mathrm{~W}$ metal halide lamps with an ultraviolet filter. Spectral correction applied. & $\mathrm{Y}$ \\
\hline Hickman & Tungsten halogen lamps behind blue light filters (no additional corrections made). & $\mathrm{N}$ \\
\hline Figueiras & $50 \mathrm{~W}(12 \mathrm{~V})$ tungsten halogen lamp. Spectral correction applied. & Y \\
\hline Gudmundsson & Fluorescent tubes (Philips TLF $20 \mathrm{~W} / 33$ ). No additional corrections made. & $\mathrm{N}$ \\
\hline Doblin & $\begin{array}{l}\text { Cool daylight fluorescent tubes (Philips TLD } 36 \text { W/54). A mix of grey and blue filters (Rosco } \\
3402,50 \% \text { neutral density filter, i.e. grey strips, and Rosco } 3204 \text { half blue) were used to atten- } \\
\text { uate the light intensity in the incubator. }\end{array}$ & $\mathrm{N}$ \\
\hline
\end{tabular}

provide intensities sufficiently high to resemble irradiances at the sea surface $\left(\sim 2000 \mu\right.$ molquanta $\left.\mathrm{m}^{-2} \mathrm{~s}^{-1}\right)$. One limitation of using tungsten lamps is that they have a spectrum heavily weighted towards the red and infrared (see Fig. 2), unless the light first passes through a filter that removes the red emission. Table 4 describes the various lamps and filters used in the $P-E$ incubators used in this study.

To estimate the impact of a tungsten halogen lamp compared with a white light source on the magnitude of the $\alpha^{B}$ and consequently $E_{k}$, which is derived from estimates of $\alpha^{B}$ (Eq. 2), we used a data set from the North Atlantic that spanned several decades. From 1994, P-E data have been corrected for the spectrum of the lamp source following the method of Kyewalyanga et al. (1997), whereas prior to 1994, no correction was made due to a lack of information on the excitation spectrum of the lamp and the absorptive properties of the phytoplankton communities. By comparing data from similar regions and seasons as lamp sources have changed, we are able to assess how the light source may cause variability in the photosynthetic parameter $\alpha^{B}$. In the post-1994 data set, with corresponding lamp and absorption spectra, the correction factor $X$ varied from 1.30 to 2.06 (mean $=1.70$ with 


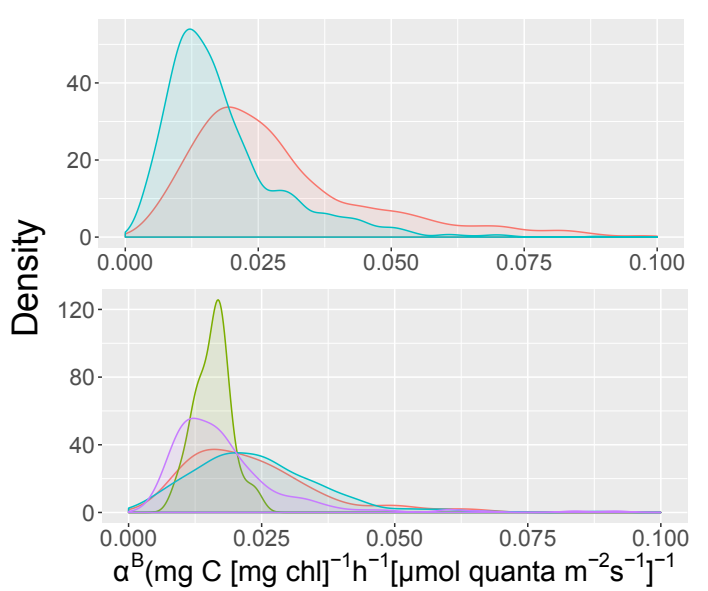

Figure 3. (a) Density plots of the initial slope $\left(\alpha^{B}\right)$ obtained using a tungsten halogen lamp (cyan) and corrected values using the shape of the phytoplankton absorption spectrum (red) as described in Kyewalyanga et al., 1997. (b) Density plots of data collected in the North Atlantic using different lamp types (red - GTE Sylvania PAR 150; green - combination of GTE Sylvania PAR 150 (irradiances $<200 \mathrm{~W}$ ) and New Haline OHS tungsten halogen (irradiances 200-1000 W); cyan - New Haline OHS 2000 tungsten halogen; purple - Gilway Technical Lamp L 7391 tungsten halogen). Both plots are using data collected within the top $20 \mathrm{~m}$ of the water column.

a standard deviation of 0.15 ). This variation in $X$ (Fig. 3a) is sufficient to account for difference in magnitudes of $\alpha^{B}$ obtained using incubators with different light sources across the North Atlantic cruise data set (Fig. 3b). Note that potential errors in the computation of primary production due to changes in $\alpha^{B}$ caused by spectral differences in light sources will be most acute deeper in the water column, where the influence of the magnitude of $\alpha^{B}$ on primary production is greatest (Ulloa et al., 1997; Bouman et al., 2000a) and thus errors for integrated water-column primary production will be modest since productivity rates are highest at the surface and decrease in an exponential manner once $E(z) \ll E_{k}$ (Ulloa et al., 1997; Bouman et al., 2000a).

\subsubsection{Theoretical maxima}

The photophysiological constraints of marine phytoplankton are well known and provide a useful check on the quality of the carbon-uptake experiments. The theoretical maximum quantum yield of carbon fixation $\left(\phi_{\mathrm{m}}^{T}\right)$ is $0.125 \mathrm{molC}^{\text {(mol quanta) }}{ }^{-1}$ (Platt and Jassy, 1976; Sakshaug et al., 1997). The realised maximum quantum yield of photosynthesis $\left(\phi_{\mathrm{m}}\right)$ is calculated by dividing $\alpha^{B}$ by $\bar{a}^{*}$, the chlorophyll-specific absorption coefficient of phytoplankton averaged over the visible spectrum (Platt and Jassby, 1976), and multiplying by a factor of 0.0231, which converts milligrams to moles of $\mathrm{C}$, micromoles to moles of photons, and hours to seconds. Values of $\phi_{\mathrm{m}}$ were calculated using either simultaneous measurements of $\bar{a}^{*}$, or estimates derived from a global relationship between chlorophyll concentrations and $\bar{a}^{*}$ (Bouman, unpublished data) and samples with $\phi_{\mathrm{m}}$ well above the theoretical maximum $\left(>0.15 \mathrm{molC}(\text { mol quanta })^{-1}\right)$ were discarded from the database. We also set a lower limit for the light saturation parameter $P_{m}^{B}$ of $0.2 \mathrm{mgC}(\mathrm{mgChl} a)^{-1} \mathrm{~h}^{-1}$ and the initial slope $\alpha^{B}$ of $0.002 \mathrm{mg} \mathrm{C}(\mathrm{mg} \mathrm{Chl} a)^{-1} \mathrm{~h}^{-1}\left(\mu \text { mol quanta } \mathrm{m}^{-2} \mathrm{~s}^{-1}\right)^{-1}$. Data from experiments on sea-ice algae with $\mathrm{Chl} a$ concentrations exceeding $50 \mathrm{mg} \mathrm{Chl} a \mathrm{~m}^{-3}$ were also removed. Using these criteria, 278 experiments were excluded from the global database.

\section{Results}

\subsection{Spatio-temporal patterns of the MAPPS P-E database}

In this study we adopt the Longhurst's (2007) geographical classification system of domains and provinces to partition the global data set according to the prevailing physical conditions that shape the structure and function of phytoplankton communities over large (basin) scales. The rationale behind using Longhurst's approach to estimate primary productivity is that physical forcing dictates the supply of nutrients and the average irradiance within the surface mixed layer and these factors directly impact the physiological capacity of algal cells. The four domains (also referred to as Longhurst biomes) are found in each ocean basin and are subject to distinct mechanisms of physical forcing: in the polar domain the density structure of the surface layer is strongly influenced by sea-ice melt; in the westerlies domain the mixed layer dynamics are governed by a local balance of heat-driven stratification and wind-driven turbulent mixing by winds; and in the trades domain, the depth of the mixed layer is governed by geostrophic responses to seasonal changes in the strength and location of the trade winds, while in the coastal domain, terrestrial influx of freshwater and interaction of local winds with topography play a critical role in governing ecosystem properties. The next level of partition is biogeochemical provinces, which embrace a wider set of environmental factors that govern regional ocean circulation and stratification that in turn influence ecological structure. Although it would be preferable that both domain and provincial boundaries were dynamic to accommodate seasonal, annual and decadal changes in ocean circulation (Devred et al., 2007), to exploit the entire MAPPS $P-E$ parameter data set, which contains a large number samples that were collected prior to the launch of ocean-colour satellites, we used the fixed rectilinear boundaries of Longhurst (2007) with the understanding that some of the within-province variability may be the result of the estimated and actual provincial boundaries being spatially offset. Thus, for each data point, a Longhurst province was assigned based on geographic location and is 


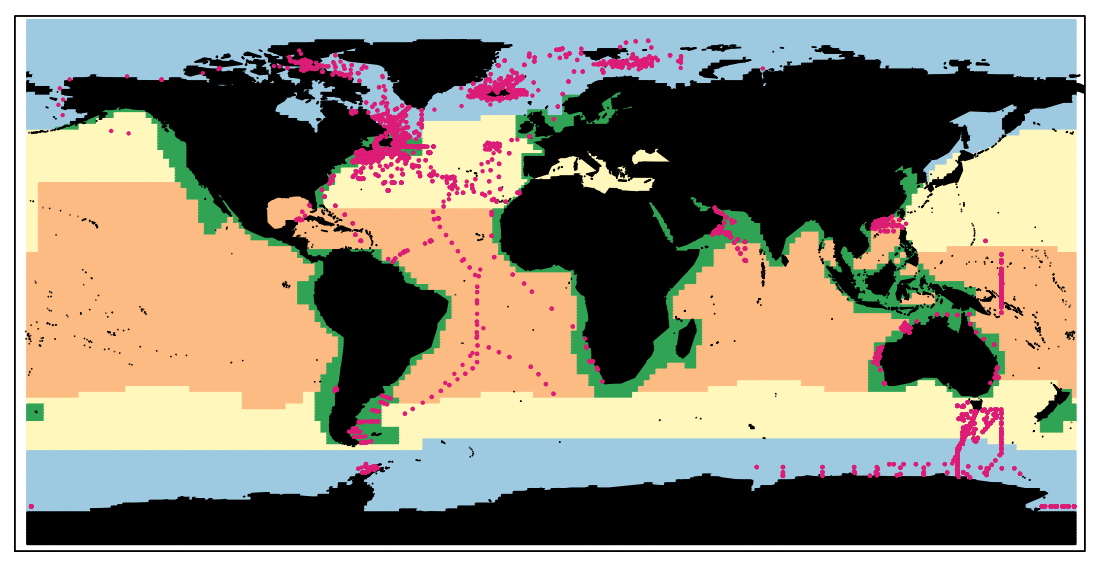

Figure 4. Global distribution of MAPPS $P-E$ data set that passed quality control (5711 samples). The blocked colours represent the four primary biomes as described in Longhurst (2007): Polar (blue), Westerlies (yellow), Trades (orange) and Coastal (green).

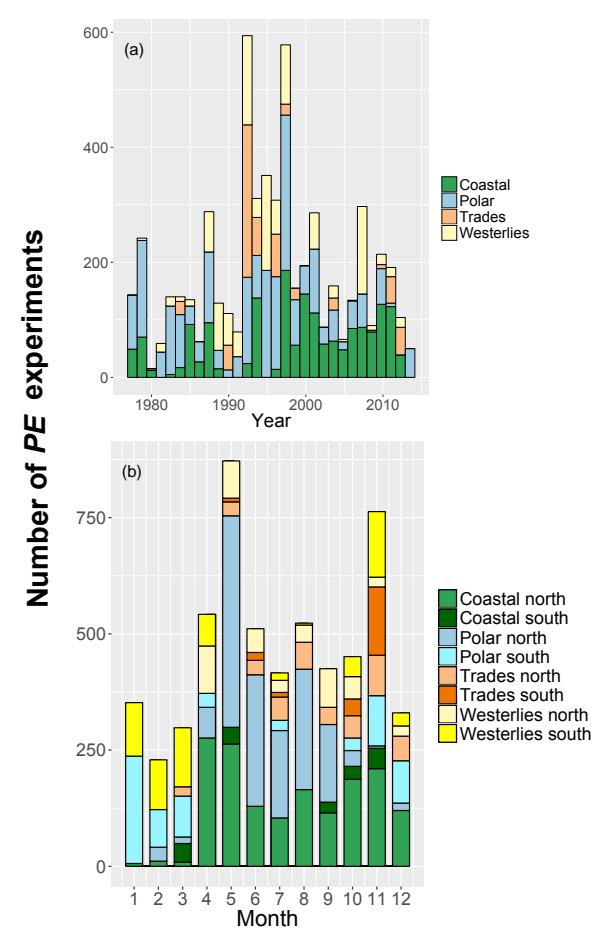

Figure 5. The number of $P-E$ experiments in the MAPPS database for the four Longhurst oceanic domains by (a) year and (b) month and hemisphere (north and south).

denoted in the database by the province number as shown in Table 1.

Roughly half of the quality-controlled samples were collected from within the upper $20 \mathrm{~m}$ of the water column, accounting for approximately $54 \%$ of the data set. Most of the data fall within the Atlantic Basin (Fig. 4), with a large region of the Pacific Basin being grossly undersampled in both space and time. The latitudinal coverage of the database is relatively sparse in the tropics and the mid-latitudes of the
Southern Hemisphere. In this study seasons were divided into 3-month intervals in order for data to be used with monthly climatologies and satellite composite data. Thus, in the case of the Northern Hemisphere, "spring" covers the months of March to May, "summer" covers June to August, "autumn" covers September to November and "winter" covers December to February. The seasonal distribution of data shows the majority of samples were collected during the spring $(40 \%)$, summer (34\%) and autumn (22\%), and only $3 \%$ of the samples collected during the winter period (Table 2, Fig. 5). Across all seasons, the data set covers a range of trophic conditions, with chlorophyll $a$ concentrations representative of highly oligotrophic conditions $\left(0.02 \mathrm{mg} \mathrm{m}^{-3}\right)$ to spring bloom conditions $\left(39.8 \mathrm{mg} \mathrm{m}^{-3}\right)$ (Fig. 6). The dynamic range of the photosynthetic parameters was similar to that reported in other global studies, with values $P_{m}^{B}$ ranging from 0.21 and $25.91 \mathrm{mgC}(\mathrm{mgChl} a)^{-1} \mathrm{~h}^{-1}$ with an average value of 3.11 and a standard deviation of 2.28, and values of $\alpha^{B}$ ranging from 0.002 to $0.373 \mathrm{mgC}(\mathrm{mgChl} a)^{-1} \mathrm{~h}^{-1}\left(\mu \text { mol quanta } \mathrm{m}^{-2} \mathrm{~s}^{-1}\right)^{-1}$ with an average value of 0.043 and a standard deviation of 0.034 .

The $P-E$ parameters exhibited both spatial (between provinces) and temporal (between seasons) differences. In general, values of the assimilation number increased with decreasing latitude (Table 5) and tended to be higher during the summer months in temperate marine systems. However, the seasonal and latitudinal bias in data coverage has important implications for variability in parameter values in the data set because of the environmental conditions known to influence phytoplankton photophysiology. High-latitude samples will be associated with lower temperatures, which may limit their maximum photosynthetic rate for carbon fixation (Smith Jr. and Donaldson et al., 2015), and this is reflected in the generally low values of $P_{m}^{B}$ in the boreal (BPLR) and austral (APLR) polar provinces. Geographical variation in surface irradiance may also explain the lower values of $P_{m}^{B}$ in high latitudes compared with low latitudes. The combina- 
Table 5. Seasonal mean values and standard deviation for the photosynthetic parameters $P_{m}^{B}$ and $\alpha^{B}$ for each of the 35 Longhurst provinces. The blocked data represent the four primary biomes of the upper ocean: Polar (first quarter), Westerlies (second quarter), Trades (third quarter) and Coastal (fourth quarter).

\begin{tabular}{|c|c|c|c|c|c|c|c|c|c|c|c|c|c|c|c|c|c|c|c|c|}
\hline \multirow[t]{3}{*}{ PROV } & \multicolumn{5}{|c|}{ Spring } & \multicolumn{5}{|c|}{ Summer } & \multicolumn{5}{|c|}{ Autumn } & \multicolumn{5}{|c|}{ Winter } \\
\hline & \multicolumn{3}{|c|}{$P_{m}^{B}$} & \multicolumn{2}{|c|}{$\alpha^{B}$} & \multicolumn{3}{|c|}{$P_{m}^{B}$} & \multicolumn{2}{|c|}{$\alpha^{B}$} & \multicolumn{3}{|c|}{$P_{m}^{B}$} & \multicolumn{2}{|c|}{$\alpha^{B}$} & \multicolumn{3}{|c|}{$P_{m}^{B}$} & \multicolumn{2}{|c|}{$\alpha^{B}$} \\
\hline & $N$ & Mean & SD & Mean & SD & $N$ & Mean & SD & Mean & SD & $N$ & Mean & SD & Mean & SD & $N$ & Mean & SD & Mean & SD \\
\hline \multicolumn{21}{|l|}{ Polar } \\
\hline BPLR & 194 & 1.86 & 0.91 & 0.037 & 0.032 & 385 & 1.93 & 1.29 & 0.030 & 0.031 & 50 & 2.10 & 1.12 & 0.029 & 0.022 & 13 & 1.56 & 0.76 & 0.019 & 0.007 \\
\hline ARCT & 421 & 2.46 & 1.52 & 0.047 & 0.031 & 203 & 2.38 & 1.27 & 0.042 & 0.028 & 37 & 2.53 & 0.84 & 0.056 & 0.032 & 18 & 2.30 & 0.73 & 0.023 & 0.008 \\
\hline SARC & 150 & 2.67 & 1.18 & 0.046 & 0.023 & 41 & 3.08 & 2.38 & 0.045 & 0.022 & 2 & 1.40 & 0.46 & 0.088 & 0.045 & 0 & & & & \\
\hline ANTA & 79 & 3.55 & 1.69 & 0.101 & 0.047 & 145 & 3.50 & 1.70 & 0.051 & 0.023 & 78 & 3.50 & 1.70 & 0.051 & 0.023 & 22 & 4.18 & 2.21 & 0.096 & 0.026 \\
\hline APLR & 119 & 1.84 & 1.22 & 0.044 & 0.023 & 222 & 1.79 & 1.05 & 0.042 & 0.019 & 12 & 1.79 & 1.05 & 0.042 & 0.019 & 0 & & & & \\
\hline BERS & 0 & & & & & 0 & & & & & 3 & 3.43 & 2.03 & 0.059 & 0.043 & 0 & & & & \\
\hline \multicolumn{21}{|c|}{ Westerlies } \\
\hline NADR & 40 & 3.49 & 1.13 & 0.033 & 0.010 & 5 & 4.41 & 4.64 & 0.029 & 0.025 & 48 & 2.10 & 1.06 & 0.028 & 0.018 & 0 & & & & \\
\hline GFST & 55 & 4.41 & 2.40 & 0.031 & 0.013 & 12 & 3.57 & 2.30 & 0.016 & 0.007 & 32 & 3.41 & 1.85 & 0.056 & 0.039 & 0 & & & & \\
\hline NASW & 85 & 5.92 & 3.30 & 0.026 & 0.014 & 91 & 1.72 & 1.34 & 0.025 & 0.022 & 35 & 3.67 & 2.15 & 0.066 & 0.072 & 0 & & & & \\
\hline NASE & 15 & 2.63 & 1.42 & 0.030 & 0.006 & 6 & 4.02 & 1.88 & 0.031 & 0.013 & 37 & 3.17 & 2.65 & 0.057 & 0.042 & 0 & & & & \\
\hline PSAE & 0 & & & & & 0 & & & & & 2 & 3.41 & 1.05 & 0.034 & 0.010 & 0 & & & & \\
\hline TASM & 0 & & & & & 7 & 2.89 & 1.59 & 0.057 & 0.022 & 16 & 7.18 & 2.20 & 0.070 & 0.017 & 0 & & & & \\
\hline SSTC & 50 & 6.81 & 4.58 & 0.076 & 0.033 & 116 & 3.10 & 2.19 & 0.035 & 0.025 & 6 & 4.24 & 0.37 & 0.035 & 0.008 & 6 & 6.36 & 2.94 & 0.066 & 0.008 \\
\hline SANT & 162 & 4.67 & 2.35 & 0.085 & 0.040 & 165 & 3.34 & 2.19 & 0.066 & 0.041 & 107 & 3.88 & 1.55 & 0.054 & 0.018 & 14 & 4.69 & 1.94 & 0.075 & 0.024 \\
\hline KURO & 6 & 9.25 & 4.25 & 0.027 & 0.009 & 0 & & & & & 1 & 10.50 & & 0.023 & & 0 & & & & \\
\hline \multicolumn{21}{|l|}{ Trades } \\
\hline NATR & 6 & 3.33 & 2.29 & 0.037 & 0.017 & 66 & 2.54 & 1.50 & 0.057 & 0.048 & 20 & 2.97 & 2.69 & 0.041 & 0.035 & 0 & & & & \\
\hline WTRA & 0 & & & & & 8 & 5.08 & 4.53 & 0.064 & 0.015 & 17 & 1.34 & 0.63 & 0.022 & 0.020 & & & & & \\
\hline ETRA & 11 & 3.00 & 0.96 & 0.027 & 0.011 & 0 & & & & & 0 & & & & & 0 & & & & \\
\hline SATL & 48 & 1.29 & 0.65 & 0.027 & 0.024 & 0 & & & & & 2 & 3.58 & 2.47 & 0.028 & 0.016 & 0 & & & & \\
\hline CARB & 20 & 3.71 & 2.16 & 0.011 & 0.005 & 0 & & & & & 15 & 2.15 & 1.75 & 0.026 & 0.020 & 0 & & & & \\
\hline MONS & 0 & & & & & 0 & & & & & 62 & 4.05 & 2.04 & 0.024 & 0.007 & 4 & 5.66 & 1.60 & 0.026 & 0.005 \\
\hline WARM & 0 & & & & & 64 & 2.23 & 1.67 & 0.039 & 0.027 & 167 & 2.44 & 1.65 & 0.032 & 0.019 & 0 & & & & \\
\hline $\mathrm{ARCH}$ & 70 & 3.62 & 3.41 & 0.034 & 0.016 & 0 & & & & & 30 & 5.86 & 3.72 & 0.025 & 0.009 & 18 & 3.89 & 3.09 & 0.034 & 0.030 \\
\hline NPTG & 0 & & & & & 0 & & & & & 4 & 2.62 & 1.99 & 0.054 & 0.074 & 0 & & & & \\
\hline \multicolumn{21}{|l|}{ Coastal } \\
\hline CHIL & 7 & 2.50 & 0.93 & 0.029 & 0.004 & 0 & & & & & 0 & & & & & 0 & & & & \\
\hline NECS & 29 & 3.20 & 1.07 & 0.023 & 0.010 & 0 & & & & & 1 & 2.22 & & 0.062 & & 0 & & & & \\
\hline CNRY & 0 & & & & & 0 & & & & & 23 & 4.62 & 1.40 & 0.065 & 0.017 & 0 & & & & \\
\hline AUSW & 44 & 3.04 & 2.02 & 0.038 & 0.015 & 15 & 2.61 & 1.93 & 0042 & 0.026 & 16 & 2.12 & 1.67 & 0.032 & 0.017 & 0 & & & & \\
\hline BRAZ & 9 & 2.37 & 1.86 & 0.041 & 0.035 & 5 & 3.63 & 2.05 & 0.014 & 0.005 & 0 & & & & & 1 & 0.87 & & 0.019 & \\
\hline REDS & 0 & & & & & 4 & 4.13 & 2.07 & 0.022 & 0.006 & 0 & & & & & 0 & & & & \\
\hline ARAB & 0 & & & & & 132 & 4.07 & 1.67 & 0.021 & 0.008 & 79 & 5.61 & 1.85 & 0.027 & 0.007 & 0 & & & & \\
\hline FKLD & 25 & 2.96 & 2.85 & 0.040 & 0.035 & 1 & 1.71 & & 0.010 & & 19 & 1.85 & 1.00 & 0.017 & 0.006 & 9 & 1.06 & 0.43 & 0.012 & 0.003 \\
\hline BENG & 0 & & & & & 0 & & & & & 20 & 3.82 & 2.13 & 0.027 & 0.011 & 0 & & & & \\
\hline CHIN & 24 & 7.50 & 3.68 & 0.029 & 0.012 & 37 & 6.87 & 5.18 & 0.023 & 0.016 & 17 & 8.92 & 4.45 & 0.033 & 0.015 & 0 & & & & \\
\hline NWCS & 543 & 2.78 & 1.93 & 0.039 & 0.033 & 259 & 3.34 & 1.90 & 0.025 & 0.030 & 405 & 3.86 & 1.94 & 0.042 & 0.034 & 42 & 2.79 & 1.47 & 0.042 & 0.034 \\
\hline
\end{tabular}

tion of lower surface irradiances and deep convective mixing in high latitudes results in markedly lower light levels within the mixed layer, which may result in photoacclimation to lower light levels, by modulating pigment content per cell and hence the carbon-to-chlorophyll ratio (Cullen et al., 1982; Sathyendranath et al., 2009). However, it is important to note that some of the polar samples were collected in regions highly influenced by sea-ice melt, which may lead to the formation of a fresh, shallow and highly stable mixed layer, and consequently higher average light level than would be the case for deeper mixing.

The paucity of winter data reduces the number of samples with cells acclimated to low growth irradiances. The number of observations is also low within the tropical and subtropical oceans, which are characterised by warm and hence strongly stratified mixed layers. Phytoplankton cells in these regions tend to have higher upper bounds of $P_{m}^{B}$, due to the combined effect of warmer sea-surface temperatures and the acclimation to high-light conditions. Such spatio-temporal patterns in the $P-E$ parameters are likely driven by changes in oceanographic conditions (temperature, stratification, macro- and micronutrient availability) (Geider et al., 1996) as well as in community structure and other biotic processes that may consume cellular energy at the expense of carbon fixation (Puxty et al., 2016).

To examine whether spatial variation in the photosynthetic parameters for a given season was captured in the boundaries of the Longhurst provinces, we conducted the Bonferroni adjusted pairwise $t$ tests to analyse differences between adjacent provinces for each season (Fig. 7). For both photosynthetic parameters differences across the boundaries were detected in polar regions and in seasons and provinces where 

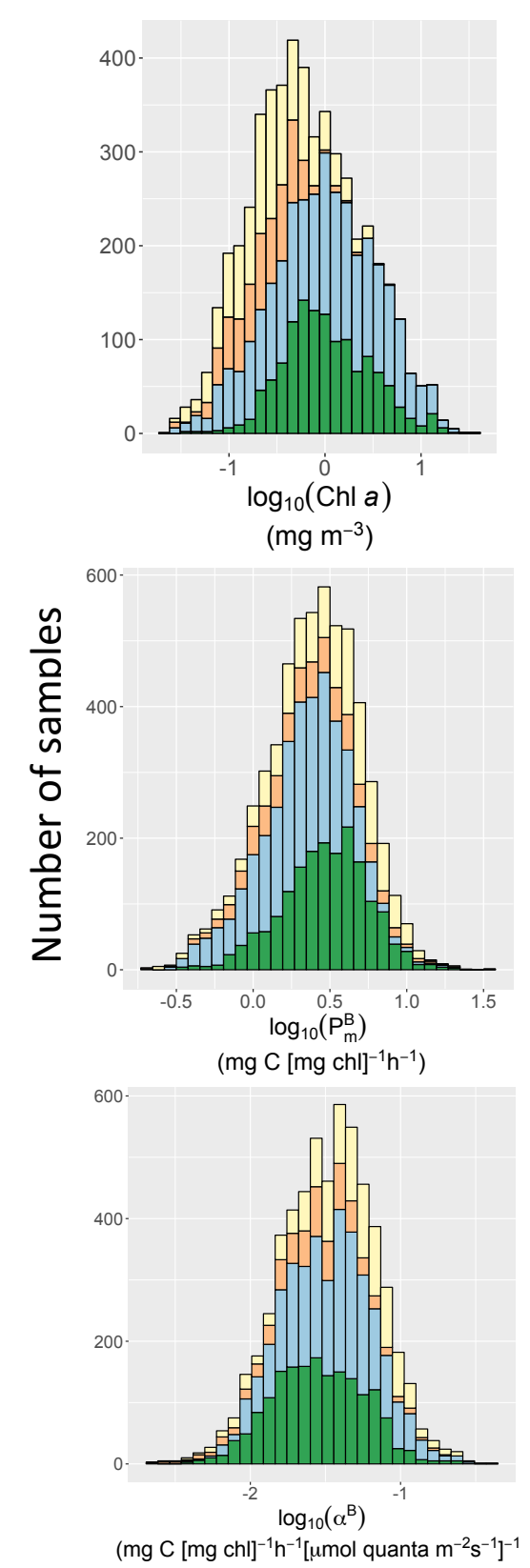

Figure 6. Histograms illustrating the sample distribution across concentrations of chlorophyll $a$ and range of $P-E$ parameter values for the four Longhurst oceanic domains.

the number of observations tended to be high. The static nature of the province boundaries and the uneven spatial distribution of the data may explain in part the small number of differences in the $P-E$ parameters between adjacent provinces.

\subsection{Relationship between the maximum photosynthetic rate and the initial slope}

Strong correlations have been reported between the two $P-E$ parameters $P_{m}^{B}$ and $\alpha^{B}$, which have been explained on both ecological and photophysiological grounds (Platt and Jassby, 1976; Côté and Platt, 1983; Behrenfeld et al., 2004). The MAPPS data set shows that the data fall largely within the bounds of $E_{k}$ values between 20 and $300 \mu$ molquanta $\mathrm{m}^{-2} \mathrm{~s}^{-1}$ (Fig. 8). In general, high-latitude samples $\left(>65^{\circ}\right)$ tend to have lower $P_{m}^{B}$ values for a given value of $\alpha^{B}$ ( $E_{k}$ values averaging $57.7 \mu$ molquanta $\mathrm{m}^{-2} \mathrm{~s}^{-1}$, with $10.0 \%$ of the data falling above $100 \mu$ molquanta $\mathrm{m}^{-2} \mathrm{~s}^{-1}$ ) when compared with lowlatitude samples between $40^{\circ} \mathrm{N}$ and $40^{\circ} \mathrm{S}\left(E_{k}\right.$ values averaging $152.4 \mu \mathrm{molquanta} \mathrm{m}^{-2} \mathrm{~s}^{-1}$, with $57.1 \%$ of the values falling above $100 \mu \mathrm{mol}$ quanta $\mathrm{m}^{-2} \mathrm{~s}^{-1}$ ).

When $E_{k}$ is plotted as a function of latitude (Fig. 9) for open-ocean samples within the top $25 \mathrm{~m}$ of the water column, a clear pattern emerges, with higher latitude samples being characterised by lower values, whereas data from the mid- to low latitudes had, on average, higher values, although considerable scatter was observed over the entire range of temperatures. To illustrate the depth-dependent change in $E_{k}$ due to vertical changes in irradiance, data from cruises that predominantly sampled stratified, oligotrophic regions (DCM and AMT cruises) are plotted against the sample depth (Fig. 10). The strong depth dependence of the photoacclimation parameter is consistent with other open-ocean studies (Babin et al., 1996). The latitudinal and depth dependence of $E_{k}$ was also reported in a study which used a subset $(N=1862)$ of the MAPPS database from the North Atlantic spanning the tropics to the Arctic: $55 \%$ of the variance in $E_{k}$ could be explained using depth, latitude, temperature, nitrate and surface noon irradiance as predictive variables (Platt and Sathyendranath, 1995).

\section{Discussion}

Predicting the photosynthetic efficiency of phytoplankton cells remains one of the major challenges in determining marine primary production using remote sensing data (Carr et al., 2006). The MAPPS database of $P-E$ parameters allows us to assess the global variability in phytoplankton photophysiological parameters and could be used to validate models that aim to provide a mechanistic understanding of changes in the photosynthetic parameters. Here, we attempt to explain the spatial patterns in the data set drawing on our current understanding of the key environmental factors governing variability in both $P_{m}^{B}$ and $\alpha^{B}$.

A positive correlation between $P_{m}^{B}$ and $\alpha^{B}$ has been attributed to a variety of physiological and ecological factors, including changes in the allocation of ATP and NADPH to carbon fixation (Behrenfeld et al., 2004), as well as changes in phytoplankton community structure (Côté and 


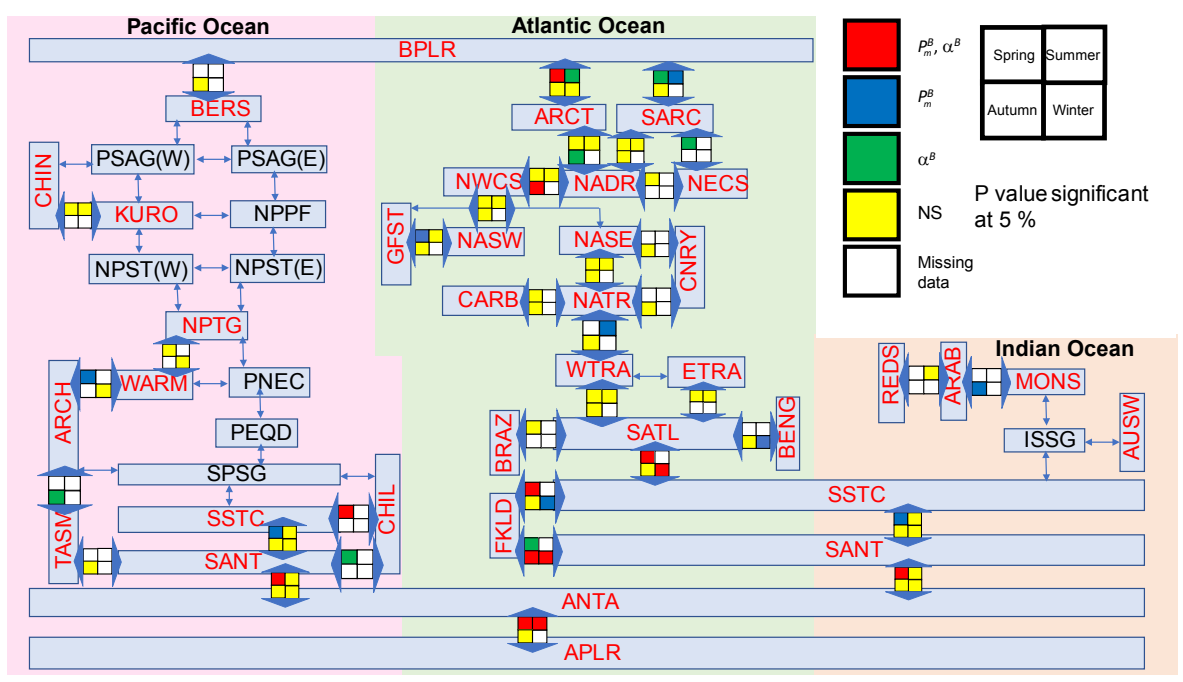

Figure 7. Diagram illustrating the seasonal differences of the $P-E$ parameters between adjacent provinces by pairwise comparisons using Bonferroni adjusted $t$ tests. Colours of blocks denote significance at the $5 \%$ level. Note the orientation of the four blocks representing the seasonal difference remains as shown in the legend for both vertical and horizontal comparisons.

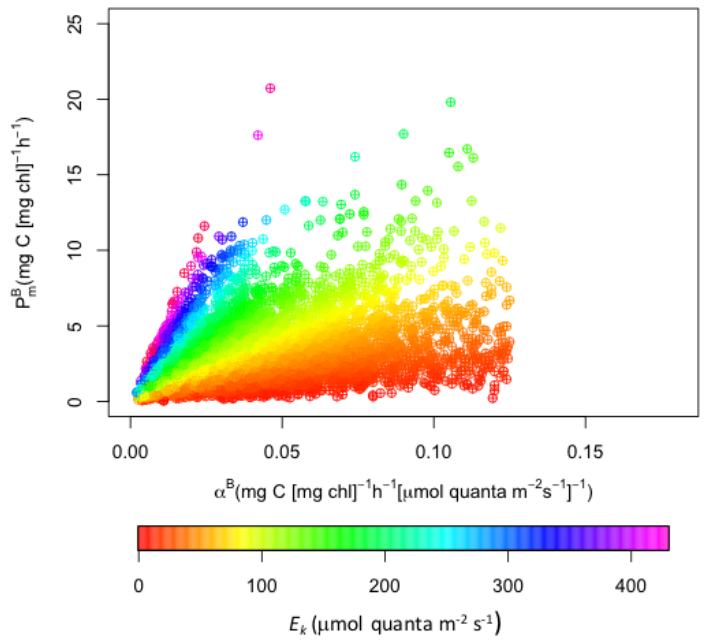

Figure 8. The assimilation number $\left(P_{m}^{B}\right)$ plotted against the initial slope $\left(\alpha^{B}\right)$. Symbol colours represent the value of $E_{k}$ in units of umol quanta $\mathrm{m}^{-2} \mathrm{~s}^{-1}$.

Platt, 1983). To disentangle the ecological from the physiological sources of variability is not straightforward, unless additional information on the taxonomic composition and photoacclimatory status of natural phytoplankton samples is available. Moreover, culture studies have invoked viral infection as another potential source of variability that is poorly understood in natural marine systems (Puxty et al., 2016).

Both taxon-specific and size-specific differences in $P_{m}^{B}$ and $\alpha^{B}$ have been reported in both culture and field studies (Bouman et al., 2005; Côté and Platt, 1983, 1984; Huot et al., 2013; Xie et al., 2015). As new remote-sensing algorithms are now starting to yield information on the size

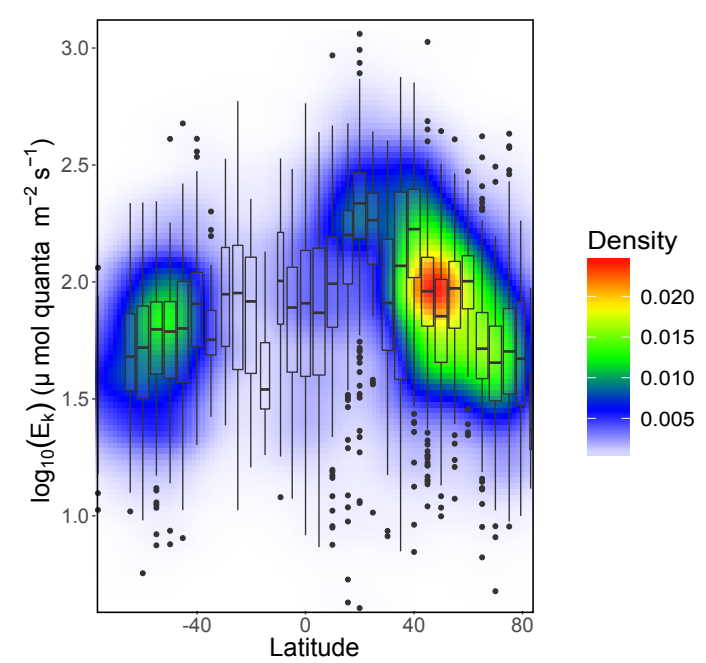

Figure 9. Density plot and box plots showing the variation in the photoadaptation parameter $\left(E_{k}\right)$ with latitude. Middle horizontal line of boxplot represents the median value and lower and upper boundaries correspond to the first and third quartiles and the length of the whiskers is 1.5 times the inter-quantile range of the boundary. Heat map indicates probability density estimates. Filled circles denote outliers.

and taxonomic structure of phytoplankton, it would be useful to derive additional information on the $P-E$ response of key phytoplankton taxa and size classes, especially those implicated as playing key roles in ocean biogeochemical cycles (LeQuéré et al., 2005; Nair et al., 2008; Bracher et al., 2017). Although detailed information on the taxonomic and size structure of ship-based experiments was lacking for several of the samples included in this data set, more recent studies 


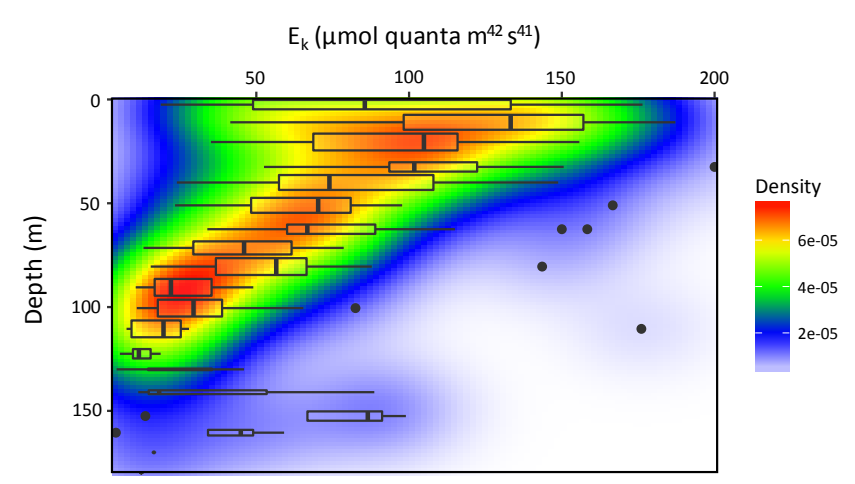

Figure 10. Density plot and box plots showing variation in the photoadaptation parameter $\left(E_{k}\right)$ with depth for research cruises focussed on the oligotrophic gyres (DCM, AMT6, AMT15, AMT20 and AMT22). Middle horizontal line of boxplot represents the median value and lower and upper boundaries correspond to the first and third quartiles and the length of the whiskers is 1.5 times the inter-quantile range of the boundary. Heat map indicates probability density estimates. Filled circles denote outliers.

include some measure of phytoplankton community structure, whether it be from use of pigment markers, size fraction of pigment and/or productivity, or cell counts. As information on the global distribution of key phytoplankton groups is becoming available from global studies of phytoplankton pigment markers and flow cytometric counts (Buitenhuis et al., 2012; Peloquin et al., 2013; Swan et al., 2015), links between phytoplankton biogeography and large-scale pattern in photophysiology as revealed through the $P-E$ parameters may be explored. Although there is a question as to what the standard indices of community structure should be that can help account for community-based variation in the photophysiological parameters across oceanographic data sets (Bracher et al., 2017), it is likely that information on gross community structure alone will not account for a large fraction of the variability in $P-E$ parameters, especially across regions or seasons with different environmental forcing (Bouman et al., 2005; Smith Jr. and Donaldson, 2015) or resident ecotypes (Geider and Osborne, 1991). Establishing relationships between taxonomic composition and phytoplankton photophysiology will require simultaneous measurements of community structure alongside photosynthesis-irradiance experiments.

The high range of photosynthetic parameters recorded at lower latitudes is largely caused by depth-dependent changes due to photoacclimation and photoadaptation (Babin et al., 1996; Bouman et al., 2000b; Huot et al., 2007) in highly stratified waters. Strong vertical gradients in nutrient supply and growth irradiance lead to a vertical layering of ecological niches, resulting in strong vertical gradients in species composition, and in the case of marine picocyanobacteria, high-light and low-light ecotypes are observed (Johnson et al., 2006; Zwirglmaier et al., 2007). Al- though depth-dependent variability in the photosynthetic parameters can be examined in the MAPPS data set, in particular $E_{k}$ (Fig. 10), it has been argued that optical depth may be a more useful predictor of changes in the $P-E$ parameters resulting from vertical changes in the photoacclimatory status of phytoplankton cells (Babin et al., 1996; Bouman et al., 2000b). In highly stratified and stable seas such as the oligotrophic gyres this may be the case, yet in more dynamic ocean conditions such as the Beaufort Sea, optical depth has been shown to have no more predictive skill, and sometimes less, than using depth alone (Huot et al., 2013). It is important to note that diel changes in the $P-E$ parameters were not taken into account in this meta-analysis due to a lack of information on the time of sample collection in a significant number of observations, which can be a significant source of variability (MacCaull and Platt, 1977; Prézelin and Sweeney, 1977; Prézelin et al., 1986; Harding et al., 1983; Cullen et al., 1992; Bruyant et al., 2005). However, as noted in the study of Babin and co-authors (1996) such diel and day-to-day variability in the $P-E$ parameters is likely to be far smaller when compared with differences across biogeochemical provinces subject to markedly different environmental forcing.

Clear latitudinal differences in the range of $E_{k}$ values are revealed in the MAPPS data set (Fig. 9), which suggests that $E_{k}$ may be controlled by environmental factors that vary strongly with latitude, such as temperature and the availability of light. Figure 9 shows that samples collected from high-latitude environments, such as the Labrador Sea, the (sub)Arctic and the Southern Ocean have markedly lower $E_{k}$ values, reflecting the physical constraints of low temperatures and, in some cases, low light levels (Harrison and Platt, 1986). The physical dynamics of the upper ocean and their impact on temperature and light conditions have been shown to play a dominant role in governing the photosynthetic performance of polar and temperate marine phytoplankton (Harrison and Platt, 1986; Bouman et al., 2005). Although largescale shifts in the photophysiological status of the phytoplankton are observed in the data set, spatial differences between adjacent provinces were only observed at higher latitudes and seasons where the number of experimental observations tended to be higher (Fig. 7). It is clear from this analysis that more effort must be focused on obtaining information on photophysiology in oceanic regimes that are highly undersampled both in space and time.

\section{Data availability}

The compiled data set containing 5711 individual photosynthesis-irradiance experiments and corresponding metadata are available at PANGAEA (https://doi. pangaea.de): https://doi.org/10.1594/PANGAEA.874087 (Bouman et al., 2017). 


\section{Recommendations for use}

The MAPPS database of photosynthesis-irradiance parameters may be used to compute marine primary production using remotely sensed data on ocean colour (e.g. Longhurst et al., 1995). The data present in Table 2 provide seasonal values of the photosynthetic parameters for Longhurst biogeochemical provinces, whose geographical boundaries can be found online at http://www.marineregions.org/. This data set will also serve as a useful resource for validation of other methods used to extrapolate $P-E$ parameters to basin scales using ocean observables (Antoine and Morel, 1996; Platt et al., 2008; Saux-Picart et al., 2014). The MAPPS database will allow such extrapolation procedures to be further tested and refined over a much larger range of geographical and biogeochemical domains or for new approaches of parameter assignment to be developed.

Competing interests. The authors declare that they have no conflict of interest.

Acknowledgements. The authors wish to thank Alex Poulton, Lilian Krug and one anonymous reviewer, whose helpful suggestions improved the manuscript. The authors also thank the research scientists, technicians, students and crew who contributed to the collection of these data. In particular, we acknowledge the significant contributions made by Brian Irwin, Jeff Anning, Gary Maillet, Christine Hanson, Brian Griffiths, James McLaughlin, Richard Matear, and Andy Steven. This work was funded through the European Space Agency's MAPPS (MArine primary Production: model Parameters from Space) project as part of the Support to Science Element (STSE) Pathfinders Program. This is a contribution to the NERC-funded project Arctic PRIZE (NE/P006507/1) and the Simons Foundation CBIOMES Project. This work is also a contribution to the National Centre for Earth Observation, of NERC, UK.

Edited by: Francois Schmitt

Reviewed by: Alex Poulton and one anonymous referee

\section{References}

Antoine, D. and Morel, A.: Oceanic primary production 1. Adaptation of a spectral light-photosynthesis model in view of application to satellite chlorophyll observations, Global Biogeochem. Cy., 10, 43-55, 1996.

Babin, M., Morel, A., and Gagnon, R: An incubator designed for extensive and sensitive measurements of phytoplankton photosynthetic parameters, Limnol. Oceanogr., 39, 694-702, 1994.

Babin, M., Morel, A., Claustre, H., Bricaud, A., Kolber, Z., and Falkowski, P. J.: Nitrogen- and irradiance-dependent variations of maximum quantum yield of carbon fixation in eutrophic, mesotrophic and oligotrophic marine systems, Deep-Sea Res., 43, 1241-1272, 1996.
Behrenfeld, M. J., Prasil, O., Babin, M., and Bruyant, F.: In search of a physiological basis for covariations in light-limited and light-saturated photosynthesis, J. Phycol., 40, 4-25, 2004.

Bouman, H. A., Platt, T., Sathyendranath, S., Irwin, B. D., Wernand, M. R., and Kraay, G. W.: Bio-optical properties of the subtropical North Atlantic. II. Relevance to models of primary production, Mar. Ecol.-Prog. Ser., 200, 19-34, 2000a.

Bouman, H. A., Platt, T., Kraay, G. W., Sathyendranath, S., and Irwin, B. D.: Bio-optical properties of the subtropical North Atlantic. I. Vertical variability, Mar. Ecol.-Prog. Ser., 200, 3-18, 2000b.

Bouman, H. A., Platt, T., Sathyendranath, S., and Stuart, V.: Dependence of light-saturated photosynthesis on temperature and community structure, Deep-Sea Res. Pt .I, 52, 1284-1299, 2005.

Bouman, H. A., Platt, T., Doblin, M. A., Figueiras, F. G., Gudmundsson, K., Gudfinnsson, H. G., Huang, B., Hickman, A., Hiscock, M. R., Jackson, T., Lutz, V. A., Melin, F., Rey, F., Pepin, P., Segura, V., Tilstone, G., van DongenVogels, V., and Sathyendranath, S.: A global dataset of photosynthesis-irradiance parameters for marine phytoplankton, https://doi.org/10.1594/PANGAEA.874087, 2017.

Bracher, A., Bouman, H. A., Brewin, R. J. W., Bricaud, A., Brotas, V., Ciotti, A. M., Clementson, L., Devred, E., Di Cicco, A., Dutkiewicz, S., Hardman-Mountford, N. J., Hickman, A. E., Hieronymi, M., Hirata, T., Losa, S. N., Mouw, C. B., Organelli, E., Raitsos, D. E., Uitz, J., Vogt, M., and Wolanin, A.: Obtaining phytoplankton diversity from ocean color: a scientific roadmap for future development, Front. Mar. Sci., 4, 55, https://doi.org/10.3389/fmars.2017.00055, 2017.

Bruyant, F., Babin, M. Genty, B., Prasil, O., Berhrenfeld, M. J., Claustre, H., Bricaud, A., Garczarek, L., Holtzendorff, J., Koblizek, M., Dousova, H., and Partensky, F.: Diel variations in the photosynthetic parameters of Prochlorococcus strain PCC 9511: combined effects of light and cell cycle, Limnol. Oceanogr., 50, 850-863, 2005.

Buitenhuis, E. T., Li, W. K. W., Vaulot, D., Lomas, M. W., Landry, M. R., Partensky, F., Karl, D. M., Ulloa, O., Campbell, L., Jacquet, S., Lantoine, F., Chavez, F., Macias, D., Gosselin, M., and McManus, G. B.: Picophytoplankton biomass distribution in the global ocean, Earth Syst. Sci. Data, 4, 37-46, https://doi.org/10.5194/essd-4-37-2012, 2012.

Carr, M. E., Friedrichs, M., Schmeltz, M., NoguchiAita, M., Antoine, D., Arrigo, K. R., Asanuma, I., Aumont, O., Barber, R., Behrenfeld, M. J., Bidigare, R., Buitenhuis, E., Campbell, J. W., Ciotti, A., Dierssen, H. M., Dowell, M., Dunne, J., Esaias, W., Gentili, B., Gregg, W. W., Groom, S. B., Hoepffner, N., Ishizaka, J., Kameda, T., Le Quere, C., Lohrenz, S., Marra, J., Mélin, F., Moore, K., Morel, A., Reddy, T., Ryan, J., Scardi, M., Smyth, T., Turpie, K., Tilstone, G. H., Waters, K., and Yamanaka, Y.: A comparison of global estimates of marine primary production from ocean color, Deep-Sea Res. Pt. II, 53, 741-770, 2006.

Cullen, J. J.: The deep chlorophyll maximum: comparing vertical profiles of chlorophyll a, Can. J. Fish. Aquat. Sci., 39, 791-803, 1982.

Cullen, J. J., Lewis, M. R., Davis, C. O., and Barber, R. T.: Photosynthetic characteristics and estimated growth rates indicate grazing is the proximate control of primary production in the equatorial Pacific, J. Geophys. Res., 97, 639-654, 1992. 
Côté, B. and Platt, T.: Day-to-day variations in the spring-summer photosynthetic parameters of coastal marine phytoplankton, Limnol. Oceanogr., 28, 320-344, 1983.

Côté, B. and Platt, T.: Utility of the light-saturation curve as an operational model for quantifying the effects of environmental conditions on phytoplankton photosynthesis, Mar. Ecol.-Prog. Ser., 18, 57-66, 1984.

Devred, E., Sathyendranath, S., and Platt, T.: Delineation of ecological provinces using ocean colour radiometry, Mar. Ecol.-Prog. Ser., 346, 1-13, 2007.

Dogliotti, A. I., Lutz, V. A., and Segura, V.: Estimation of primary production in the southern Argentine continental shelf and shelfbreak regions using field and remote sensing data, Remote Sens. Environ., 140, 497-508, 2014.

Geider, R. J. and Osborne, B. A.: Algal Photosynthesis: The Measurement of Gas Exchange and Related Processes, Chapman and Hall, New York, 256 pp., 1991.

Geider, R. J, MacIntyre, H. L., and Kana, T. M.: A dynamic model of photoadaptation in phytoplankton, Limnol. Oceanogr., 41, 115, 1996.

Griffiths, F. B., Bates, T. S., Quinn, P. K., Clementson, L. A., and Parslow, J. S.: Oceanographical context of the first Aerosol Characterisation Experiment (ACE-1): a physical, chemical and biological overview, J. Geophys. Res., 104, 21649-21671, 1999.

Gudmundsson, K.: Long-term variation in phytoplankton productivity during spring in Icelandic waters, ICES J. Mar. Sci., 55, 635-643, 1998.

Hanson, C. E., Pattiaratchi, C. B., Waite, A. M.: Sporadic upwelling on a downwelling coast: phytoplankton responses to spatially variable nutrient dynamics off the Gascoyne region of Western Australia, Cont. Shelf Res., 25, 1561-1582, $2005 a$.

Hanson, C. E., Pattiaratchi, C. B., and Waite, A. M.: Seasonal production regimes off south-western Australia: influence of the Capes and Leeuwin Currents on phytoplankton dynamics, Mar. Freshwater Res., 56, 1011-1026, 2005b.

Harding, L. W., Meeson, B. W., and Tyler, M. A.: Photoadaptation and diel periodicity of photosynthesis in the dinoflagellate Prorocentrum mariaelebouriae, Mar. Ecol.-Prog. Ser., 13, 73$85,1983$.

Harrison, W. G. and Platt, T.: Photosynthesis-irradiance relationships in polar and temperate phytoplankton populations, Polar Biol., 5, 153-164, 1986.

Hickman, A. E.: The photophysiology and primary productivity of phytoplankton within the deep chlorophyll maximum, doctoral thesis, University of Southampton, Southampton, UK, 237 pp., 2007.

Hiscock, M. R.: The regulation of primary productivity in the Southern Ocean, doctoral thesis, Duke University, Beaufort, USA, 120 pp., 2004.

Hiscock, M. R., Marra, J., Smith Jr., W. O., Goericke, R., Measures, C., Vink, S., Olson, R. J., Sosik, H. M., and Barber, R. T.: Primary productivity and its regulation in the Pacific Sector of the Southern Ocean, Deep-Sea Res. Pt. II, 50, 533-558, 2003.

Holm-Hansen, O., Lorenzen, C. J., Holmes, R. W., and Strickland, J. D. H.: Fluorometric determination of chlorophyll, J. Cons. Perm. Int. Explor. Mer., 30, 3-15, 1965.

Huot, Y., Babin, M., Bruyant, F., Grob, C., Twardowski, M. S., and Claustre, H.: Relationship between photosynthetic parameters and different proxies of phytoplankton biomass in the subtropical ocean, Biogeosciences, 4, 853-868, https://doi.org/10.5194/bg4-853-2007, 2007.

Huot, Y., Babin, M., and Bruyant, F.: Photosynthetic parameters in the Beaufort Sea in relation to the phytoplankton community structure, Biogeosciences, 10, 3445-3454, https://doi.org/10.5194/bg-10-3445-2013, 2013.

Jackson, T.: Phytoplankton community structure, photophysiology and primary production in the Atlantic Arctic, doctoral thesis, University of Oxford, Oxford, UK, 222 pp., 2013.

Jassby, A. D. and Platt, T.: Mathematical formulation of the relationship between photosynthesis and light for phytoplankton, Limnol. Oceanogr., 21, 540-547, 1976.

Johnson, Z. I., Zinser, E. R., Coe, A., McNulty, N. P., Woodward, E. M. S., and Chisholm, S. W.: Niche partitioning among Prochlorococcus ecotypes along ocean-scale environmental gradients, Science, 311, 1737-40, 2006.

Kyewalyanga, M. N., Platt, T., and Sathyendranath, S.: Estimation of the photosynthetic action spectrum: implication for primary production models, Mar. Ecol.-Prog. Ser., 146, 207-223, 1997.

Kyewalyanga, M. N., Platt, T., Sathyendranath, S., Lutz, V. A., and Stuart, V.: Seasonal variation in physiological parameters of phytoplankton across the North Atlantic, J. Plankton Res., 20, 17-42, 1998.

Lawrenz, E., Silsbe, G., Capuzzo, E., Ylöstalo, P., Forster, R. M., Simis, S. G. H., Prásil, O., Kromkamp, J. C., Hickman, A. E., Moore, C. M., Forget, M.-H., Geider, R. J., and Suggett, D. J.: Predicting the electron requirement for carbon fixation in seas and oceans, PLoS ONE, 8, e58137, https://doi.org/10.1371/journal.pone.0058137, 2013.

Lee, Y. J., Matrai, P. A., Friedrichs, M. A. M., Saba, V. S., Antoine, D., Ardyna, M., Asanuma, I., Babin, M., Bélanger, S., BenoîtGagné, M., Devred, E., Fernández-Méndez, M., Gentili, B., Hirawake, T., Kang, S.-H., Kameda, T., Katlein, C., Lee, S. H., Lee, Z., Mélin, F., Scardi, M., Smyth, T. J., Tang, S., Turpie, K. R., Waters, K. J., and Westberry, T. K.: An assessment of phytoplankton primary productivity in the Arctic Ocean from satellite ocean color/in situ chlorophyll $a$ based models, J. Geophys. Res., 120, 6508-6541, 2015.

Le Quéré, C., Harrison, S. P., Prentice, I. C., Buitenhuis, E. T., Aumont, O., Bopp, L., Claustre, H., da Cunha, L. C., Geider, R., Giraud, X., Klaas, C., Kohfeld, K. E., Legendre, L., Manizza, M., Platt, T., Rivkin, R. B., Sathyendranath, S., Uitz, J., Watson, A. J., and Wolf-Gladrow, D.: Ecosystem dynamics based on plankton functional types for global ocean biogeochemistry models, Glob. Change Biol., 11, 2016-2040, 2005.

Lewis, M. R. and Smith, J. C.: A small volume, short-incubation time method for measurement of photosynthesis as a function of incident irradiance, Mar. Ecol.-Prog. Ser., 13, 99-102, 1983.

Longhurst, A. R.: Ecological Geography of the Sea, Academic Press, London, 2007.

Longhurst, A., Sathyendranath, S., Platt, T., and Caverhill, C.: An estimate of global primary production in the ocean from satellite radiometer data, J. Plankton Res., 17, 1245-1271, 1995.

Lorenzo, L. M., Arbones, B., Figueiras, F. G., Tilstone, G. H., and Figueroa, F. L.: Photosynthesis, primary production and phytoplankton growth rates in Gerlache and Bransfield Straits during Austral summer: cruise FRUELA 95, Deep-Sea Res. Pt. II, 49, 707-721, 2002. 
Lutz, V. A., Segura, V., Dogliotti, A. I., Gagliardini, D. A., Bianchi, A. A., and Balestrini, C. F.: Primary production in the Argentine Sea during spring estimated by field and satellite models, J. Plankton Res., 32, 181-195, 2010.

MacCaull, W. A. and Platt. T.: Die1 variations in the photosynthetic parameters of coastal marine phytoplankton, Limnol. Oceanogr., 22, 723-731, 1977.

MacIntyre, H. L., Kana, T. M., Anning, T., and Geider, R. J.: Photoacclimation of photosynthesis irradiance response curves and photosynthetic pigments in microalgae and cyanobacteria, J. Phycol., 38, 17-38, 2002.

Mackey, D. J., Parslow, J. S., Higgins, H. W., griffiths, F. B., and O'Sullivan, J. E.: Plankton productivity and biomass in the western equatorial Pacific: biological and physical controls, Deep-Sea Res. Pt. II, 42, 499-533, 1995.

Mantoura, R. F. C., Jeffrey, S. W., Llewellyn, C. A., Claustre, H., and Morales, C. E.: Comparison between spectrophotometric, fluorometric and HPLC methods for chlorophyll analysis, in: Phytoplankton Pigments in Oceanography: Guidelines to Modern Methods, edited by: Jeffrey, S. W., Mantoura, R. F. C., and Wright, S. W., UNESCO, Paris, p. 361, 1997.

Nair, A., Sathyendranath, S., Platt, T., Morales, J., Stuart, V., Forget, M.-H., Devred, E., and Bouman, H.: Remote sensing of phytoplankton functional types, Remote Sens. Environ., 112, 33663375, 2008.

Pálsson, Ó. K., Gislason, A., Guðfinnsson, H. G., Gunnarsson, B., Ólafsdóttir, S. R., Petursdottir, H., Sveinbjörnsson, S., Thorisson, K., and Valdimarsson, H. Ecosystem structure in the Iceland Sea and recent changes to the capelin (Mallotus villosus) population, ICES J. Mar. Sci., 69, 1242-1254, https://doi.org/10.1093/icesjms/fss071, 2012.

Peloquin, J., Swan, C., Gruber, N., Vogt, M., Claustre, H., Ras, J., Uitz, J., Barlow, R., Behrenfeld, M., Bidigare, R., Dierssen, H., Ditullio, G., Fernandez, E., Gallienne, C., Gibb, S., Goericke, R., Harding, L., Head, E., Holligan, P., Hooker, S., Karl, D., Landry, M., Letelier, R., Llewellyn, C. A., Lomas, M., Lucas, M., Mannino, A., Marty, J.-C., Mitchell, B. G., MullerKarger, F., Nelson, N., O’Brien, C., Prezelin, B., Repeta, D., Jr. Smith, W. O., Smythe-Wright, D., Stumpf, R., Subramaniam, A., Suzuki, K., Trees, C., Vernet, M., Wasmund, N., and Wright, S.: The MAREDAT global database of high performance liquid chromatography marine pigment measurements, Earth Syst. Sci. Data, 5, 109-123, https://doi.org/10.5194/essd5-109-2013, 2013.

Platt, T. and Jassby, A. D.: The relationship between photosynthesis and light for natural assemblages of coastal marine phytoplankton, J. Phycol., 12, 421-430, 1976.

Platt, T., Gallegos, C. L., and Harrison, W. G.: Photoinhibition of photosynthesis in natural assemblages of marine phytoplankton, J. Mar. Res., 38, 687-701, 1980.

Platt, T., Harrison, G., Irwin, B., and Horne, E. P.: Photosynthesis and photoadaptation in the arctic, Deep-Sea Res. Pt. I, 29, 11591170, 1982.

Platt, T., Sathyendranath, S., Joint, I., and Fasham, M. J. R.: Photosynthesis characteristics of phytoplankton in the Celtic Sea during late spring, Fish. Oceanogr., 2, 191-201, 1993.

Platt, T. and Sathyendranath, S.: Latitude as a factor in the calculation of primary production, in: Ecology of Fjords and Coastal
Waters, edited by: Skjoldal, H. R., Hopkins, C., Erikstad, K. E., and Leinaas, H. P., Elsevier Science, Troms $\varnothing$, Norway, 1995.

Platt, T., Sathyendranath, S., Forget, M.-H., White III, G. N., Caverhill, C., Bouman, H., Devred, E., and Son, S.: Operational estimation of primary production at large geographical scales, Remote Sens. Environ., 112, 3437-3448, 2008.

Prézelin, B. B., Meeson, B. W., and Sweeney, B. M.: Characterization of photosynthetic rhythms in marine dinoflagellates. 1. Pigmentation, photosynthetic capacity and respiration, Plant Physiol., 60, 384-387, 1977.

Prézelin, B. B., Putt, M., and Glover, H. E.: Diurnal patterns in photosynthetic capacity and depth-dependent photosynthesisirradiance relationships in Synechococcus spp., and larger phytoplankton in three water masses in the northwest Atlantic Ocean, Mar. Biol., 92, 205-217, 1986.

Prézelin, B. B., Glover, H. R., Ver Hoven, B. M., Stenberg, D., Matlick, H. A., Schofield, O., Nelson, N. B., Wyman, M., and Campbell, L.: Blue-green light effects on light-limited rates of photosynthesis: relationship to pigmentation and productivity estimates for Synechococcus populations from the Sargasso Sea, Mar. Ecol.-Prog. Ser., 54, 121-136, 1989.

Puxty, R. J., Millard, A. D., Evans, D. J., and Scanlan, D. J.: Viruses inhibit $\mathrm{CO}_{2}$ fixation in the most abundant phototrophs on earth, Curr. Biol., 26, 1585-1589, 2016.

Rey, F.: Photosynthesis-irradiance relationships in natural phytoplankton populations of the Barents Sea, Polar Res., 10, 105116, 1991.

Sakshaug, E., Bricaud, A., Dandonneau, Y., Falkowski, P. G., Kiefer, D. A., Legendre, L., Morel, A., Parslow, J., and Takahashi, M.: Parameters of photosynthesis: definitions, theory and interpretation of results, J. Plankton Res., 19, 1637-1670, 1997.

Sathyendranath, S., Stuart, V., Irwin, B. D., Maass, H., Savidge, G., Gilpin, L., and Platt, T.: Seasonal variation in bio-optical properties of phytoplankton in the Arabian Sea (1999), Deep-Sea Res. Pt. II, 46, 633-353, 1999.

Sathyendranath, S., Stuart, V., Nair, A., Oka, K., Nakane, T., Bouman, H., Forget, M.-H., Maass, H., and Platt, T.: Carbonto-chlorophyll ratio and growth rate of phytoplankton in the sea, Mar. Ecol.-Prog. Ser., 383, 73-84, 2009.

Saux-Picart, S., Sathyendranath, S., Dowell, M., Moore, T., and Platt, T.: Remote sensing of assimilation number for marine phytoplankton, Remote Sens. Env., 146, 87-96, 2014.

Schofield, O., Prézelin, B. B., Smith, R. C., Stegmann, P. M., Nelson, N. B., Lewis, M. R., and Baker, K. S.: Variability in spectral and nonspectral measurements of photosynthetic light utilization efficiencies, Mar. Ecol.-Prog. Ser., 78, 253-271, 1991.

Segura, V., Lutz, V. A., Dogliotti, A. I., Silva, R., Negri, R., Akselman, R., and Benavides, H.: Phytoplankton functional types and primary production in the Argentine Sea, Mar. Ecol.-Prog. Ser., 491, 15-31, 2013.

Smith Jr., W. O. and Donaldson, K.: Photosynthesis-irradiance responses in the Ross Sea, Antarctica: a meta-analysis, Biogeosciences, 12, 3567-3577, https://doi.org/10.5194/bg-12-35672015, 2015.

Swan, C., Vogt, M., Gruber, N., and Laugkoetter, C.: A global seasonal surface ocean climatology of phytoplankton types based on CHEMTAX analysis of HPLC pigments, Deep-Sea Res. Pt. I, 109, 137-156, https://doi.org/10.1016/j.dsr.2015.12.002, 2015. 
Tilstone, G. H., Figueiras, F. G., Lorenzo, L. M., and Arbones, B.: Phytoplankton composition, photosynthesis and primary production during different hydrographic conditions at the Northwest Iberian upwelling system, Mar. Ecol.-Prog. Ser., 252, 89-104, 2003.

Ulloa, O., Hoepffner, N., and Larkin, D.: Depth and wavelength dependence of phytoplankton photosynthesis: implications for the remote sensing of marine primary production, Proc. SPIE 2963, Ocean Optics XIII, 1996, Halifax, Nova Scotia, Canada, https://doi.org/10.1117/12.266456, 1997.

Webb, W. L., Newton, M., and Starr, D.: Carbon dioxide exchange of Alnus rubra: a mathematical model, Oecologia, 17, 281-291, 1974.

Westwood, K. J., Griffiths, F. B., Webb, J. P., and Wright, S. W.: Primary production in the Sub-Antarctic and Polar Frontal zones south of Tasmania, Australia; SAZ-Sense survey, 2007, DeepSea Res. Pt. II, 58, 2162-2178, 2011.
Xie, Y., Bangqin, H., Lin, L., Laws, E. A., Wang, L., Shang, S., Zhang, T., and Dai, M.: Photosynthetic parameters in the northern South China Sea in relation to phytoplankton community structure, J. Geophys. Res., 120, 4187-4204, https://doi.org/10.1002/2014JC010415, 2015.

Zhai, L., Gudmundsson, K., Miller, P., Peng, W., Guòfinnsson, H., Debes, H., Hátún, H., White III, G. N., Walls, R. H., Sathyendranath, S., and Platt, T.: Phytoplankton phenology and production around Iceland and Faroes, Cont. Shelf Res., 37, 15-25, 2012.

Zwirglmaier, K., Heywood, J. L., Chamberlain, K., Woodward, E. M. S., Zubkov, M. V., and Scanlan, D. J.: Basin-scale distribution patterns of picocyanobacterial lineages in the Atlantic Ocean, Environ. Microbiol., 9, 1278-1290, 2007. 